\title{
Fruit yield of strawberry stock plants after runner tip production by different cultivars
}

\author{
Miriane Dal Picio; Jerônimo Luiz Andriolo; Djeimi Isabel Jänisch; Odair José Schmitt; Maíne Alessan- \\ dra Lerner \\ UFSM-CCR, Dep ${ }^{\text {to }}$ Fitotecnia, Av. Roraima 1000, Prédio 77, Camobi, 97105-900 Santa Maria-RS; mirianedalpicio@yahoo.com.br; \\ jeronimoandriolo@gmail.com; djeimi_agro@yahoo.com.br; odairschmitt@yahoo.com.br; mainelerner@yahoo.com.br
}

\begin{abstract}
The main objective of this research was to determine fruit yield of strawberry (Fragaria x ananassa) stock plants in a cropping system after producing runner tips and plug plants. Micropropagated stock plants were planted in a soilless growing system. Runner tips bearing at least one visible root nodule were harvested at 43, 66 and 87 days after planting, rooted and planted as multiplied stock plants for producing plug plants. Treatments consisted of micropropagated stock plants of cultivars INIAArazá, INIA Guenoa and INIA Yvapitá, planted on October $1^{\text {st }}, 2008$ (T1); multiplied stock plants planted on November $28^{\text {th }}$ (T2) and on December $21^{\text {st }}, 2008$ (T3), and on January, $10^{\text {th }}, 2009$ (T4). On May 22 $2^{\text {nd }}, 2009$, stock plants were defoliated and plug plants of the same cultivars were planted as control for fruit production. Early fruit yield and number of fruits were higher on stock plants, but fresh fruit yield was higher on control plants. Total fruit yield and number were higher on stock plants of 'INIA Arazá' and 'INIA Guenoa'. We concluded that strawberry stock plants reach higher early and total fresh fruit yield than plug transplants in the second cropping year after producing runner tips in a soilless growing system. Therefore, plants should not be discarded after the production of runner tips.
\end{abstract}

Keywords: Fragaria x ananassa, propagation, plug plants, soilless growing system.

\section{RESUMO}

Produção de frutos em plantas matrizes de morangueiro após a produção de pontas de estolões de diferentes cultivares

O objetivo desta pesquisa foi determinar o rendimento de frutos de plantas matrizes de morangueiro (Fragaria x ananassa) após a produção de pontas de estolões. Plantas matrizes micropropagadas foram plantadas em 01 de outubro de 2008, em sistema de cultivo fora do solo. Pontas de estolões com pelo menos um primórdio radicular visível foram colhidas em 43, 66 e 87 dias após o plantio, enraizadas e plantadas como plantas matrizes multiplicadas para produção de mudas com torrão. Os tratamentos consistiram de plantas matrizes das cultivares INIA Arazá, INIA Guenoa e INIA Yvapitá, micropropagadas (T1) plantadas em 01 de outubro de 2008, plantas matrizes multiplicadas plantadas em 28 de novembro de 2008 (T2), 21 de dezembro de 2008 (T3) e 10 de janeiro de 2009 (T4). Em 22 de maio de 2009, as plantas matrizes micropropagadas e multiplicadas foram desfolhadas e plantas oriundas de mudas em bandejas das mesmas cultivares foram plantadas como testemunhas. A produção precoce e o número de frutos foram maiores nas plantas matrizes, porém o peso fresco de frutos foi maior nas plantas testemunhas. A produção total e o número de frutos foram maiores nas plantas matrizes das cultivares INIA Arazá e INIA Guenoa. Concluiu-se que, em sistema de cultivo fora do solo, após a produção de pontas de estolões, plantas matrizes de morango podem chegar inicialmente a uma maior produção de frutos e produção total de frutos frescos do que os transplantes com torrão. Portanto, elas não devem ser eliminadas após a produção de pontas de estolões.

Palavras-chave: Fragaria x ananassa, propagação, mudas com torrão, sistema de cultivo fora do solo.

(Recebido para publicação em 26 de julho de 2012; aceito em 28 de maio de 2013)

(Received on July 26, 2012; accepted on May 28, 2013)

\begin{abstract}
$\mathrm{I}_{a}^{\mathrm{n}}$ Brazil, strawberry (Fragaria $\mathrm{x}$ ananassa) is grown as an annual crop using mainly short-day cultivars. Planting is done in the fall and plants grow until spring, when they begin to produce fruits. In Southern Brazil, day neutral cultivars are also grown at altitudes higher than $800 \mathrm{~m}$ for fruit production in the summer and fall. In both cases, plants are removed and discarded after the fruiting period and a new crop is planted. This practice
\end{abstract}

is carried out by using transplants produced from stock plants.

Bare root transplants produced from runner tips rooted in the soil is the traditional strawberry propagation method. In Rio Grande do Sul state, Brazil, the production of strawberry bare root transplants is inexpressive and they are imported from Argentina and Chile (Oliveira \& Scivittaro, 2006). Hence, transplants are delivered to growers often not during the best time for planting their crops. Also, the quality of these plants is variable through the years and a high rate of mortality is registered.

Nowadays, there is a trend to replace bare roots transplants by those rooted in trays using the "plug plant" method (Durner et al., 2002; Tessarioli Neto et al., 2003; Giménez et al., 2008). This method requires runner tips to be produced in the summer in order to be rooted in trays and shipped to growers. To reach this goal, stock plants 
obtained by in vitro culture are planted in hydroponic facilities in the spring to produce runner tips until late summer, which is the best time for plug plant production. After this period, stock plants are usually discarded.

In a well-conducted production system, stock plants used for plug plant production are vigorous and free of pests and diseases at the time to be discarded. Therefore, these plants could still be used for fruit production and as transplants. In fact, two-year cropping of strawberries is a technique used in many countries for amortization of production costs. However, it has been considered suitable only for marginal production regions, due to increased weed control and risk of diseases in the second cropping year. Nevertheless, such problems do not occur as often in soilless systems because they are minimized.

Although strawberry has been grown as an annual crop, it is a perennial species with reproductive and propagative phases controlled by photoperiod and temperature (Heide $\&$ Sonsteby, 2007). In the reproductive phase, vegetative organs, flowers and fruits are continuously emitted and simultaneously grown. In the propagation phase, inflorescences and fruits are replaced by stolons and runner tips. Data describing patterns of growth, dry matter accumulation and partitioning among organs of the strawberry plant in these two developmental phases are scarce in the literature. The objectives of this research were i) determine growth, development and fruit yield of strawberry stock plants in a cropping system after production of runner tips and plug plants and ii) increase knowledge about dry matter partitioning among strawberry plant organs.

\section{MATERIAL AND METHODS}

The experiment was conducted in a polyethylene greenhouse, between October $1^{\text {st }}, 2008$ and December $8^{\text {th }}$, 2009 at Universidade Federal de Santa Maria $\left(29^{\circ} 42^{\prime} \mathrm{S}, 53^{\circ} 42^{\prime} \mathrm{W}\right.$, altitude 95 $\mathrm{m})$. The climate is subtropical humid according to the Köppen's classification.
During the experimental period, the maximum, minimum and monthly average air temperatures were 22.2, 11.7 and $16.9^{\circ} \mathrm{C}$, respectively. Accumulated precipitation was $1,370 \mathrm{~mm}$ and average global solar radiation was $11.05 \mathrm{MJ}$ $\mathrm{m}^{-2}$ day $^{-1}$.

Micropropagated strawberry stock plants derived from the laboratory of the University were acclimatized in the greenhouse and planted on October $1^{\text {st }}$, 2008 , in 2.3 L polyethylene bags filled with the Plantmax HA organic substrate. The bags were placed over benches at $0.80 \mathrm{~m}$ height from soil surface and covered with white polyethylene film in a density of 12 plants $/ \mathrm{m}^{2}$. Runner tips emitted by micropropagated stock plants bearing at least one visible root nodule were harvested at $43 ; 66$ and 87 days after planting. They were rooted in trays under mist for 12 days (Durner et al., 2002). After four days of acclimatization, they were planted in bags and grown as multiplied stock plants. At the first planting season, stock plants were micropropagated, on October $1^{\text {st }}, 2008$ (T1). Afterwards, stock plants were multiplied in three periods, on November $28^{\text {th }}$ and December $21^{\text {st }}$, 2008, and January 10 $0^{\text {th }}, 2009$ (T2; T3 and $\mathrm{T} 4$, respectively). The control treatment (T5) consisted on plants from plug transplants of the same cultivars. In order to produce control plug transplants, runner tips were collected on April $10^{\text {th }}$, 2009 , rooted and acclimatized such as carried out for multiplied stock plants, and further planted in bags, on May $22^{\text {nd }}$, 2009. On that day that the control plug transplants were planted, plants from treatments $\mathrm{T} 1$ to $\mathrm{T} 4$ were defoliated by cutting manually all leaves of each plant. In the two-year cropping system of strawberries, defoliation is a practice that has been currently used (Cropspecific Protocol Strawberries, 2011). The experimental array was a split plot block randomized design, with 4 replications of 4 plants, cultivars in plots and planting times in subplots.

Three short-day strawberry cultivars from the Instituto Nacional de Investigación Agropecuaria (INIA) Uruguay were used: INIA Arazá, INIA Guenoa and INIA Yvapitá. 'INIAArazá' has an early harvest season and produces a high number of runners in the nursery. 'INIA Guenoa' has an erect plant with good architecture, equilibrated in vigor and production. 'INIA Yvapitá' has a strong and vigorous plant and produces a good number of runners in the nursery (Vicente et al., 2009).

Water and nutrients were supplied to plants by fertigation, using the nutrient solution recommended to growers for fruit production, with a $30 \%$ coefficient of waste drainage. Its composition, in $\mu \mathrm{mol} \mathrm{L}-1$, was $10.6 \mathrm{NO}_{3}^{-} ; 0.43 \mathrm{NH}_{4}^{+} ; 2$ $\mathrm{H}_{2} \mathrm{PO}_{4}^{-} ; 6.15 \mathrm{~K}^{+} ; 3.0 \mathrm{Ca}^{2+} ; 1 \mathrm{Mg}^{2+}$ and $1 \mathrm{SO}_{4}^{2-}$, and in $\mathrm{mg} \mathrm{L}^{-1}: 0.03 \mathrm{Mo} ; 0.42$ $\mathrm{B} ; 0.06 \mathrm{Cu} ; 0.50 \mathrm{Mn} ; 0.22 \mathrm{Zn}$ and 1.0 $\mathrm{Fe}$. The $\mathrm{pH}$ was 5.5 and the electrical conductivity was $1.4 \mathrm{dS} \mathrm{m}^{-1}$. Plants were fertigated three times a day during 15 minutes in winter and spring and six times a day in summer and fall.

On May $22^{\text {nd }}, 2009$, when the control plug transplants were planted, 4 stock plants were collected from T1, T2, $\mathrm{T} 3$ and T4 plots for shoot, crown and root dry weight measurements, after drying at $65^{\circ} \mathrm{C}$ until constant weight. Thereafter, border plants were not used for measurements. Number of days from planting to the beginning of flowering and to the first fruit harvest was recorded. Beginning of flowering was recorded when $50 \%$ of plants in the plot had at least one flower at anthesis. Ripe fruits with the epidermis $100 \%$ red identified as stage 87 (Meier et al., 1994) were harvested and weighted twice a week. They were counted, weighted and screened in marketable yield, with fresh weight higher than $6 \mathrm{~g}$ and without any injury or malformation (Antunes et al., 2007) and unmarketable yield. Fruit yield from the first harvesting on June $15^{\text {th }}$ to September $30^{\text {th }}, 2009$, was considered as early production and to December $3^{\text {rd }}, 2009$, as total production. The experiment was concluded on December $8^{\text {th }}, 2009$, when 4 plants from each treatment were collected for shoot, crown and root dry weight measurements, such as done for stock plants on the day the control plug transplants were planted. The difference on dry weight of stock plant organs between planting and the end of the experiment was considered as the relative growth of these plants during 
the reproductive phase of the crop.

The variables number of fruits, leaves and crowns were transformed using the expression $(\mathrm{x}+0.05)^{0.5}$. All variables were submitted to analysis of variance and the significance of differences among means was determined by the Tukey's test at 5\% probability using the Statistica Software ${ }^{\circledR}$.

\section{RESULTS AND DISCUSSION}

Early fruit yield was on average (T1T4) $327.9 \%$; 213\% and 322.9\% higher on 'Arazá', 'Guenoa' and 'Yvapitá' stock plants, respectively, when compared to control plug transplants (Table 1). These results can be attributed to a higher number of fruits per plant, being $495.7 \% ; 304.7 \%$ and $257.7 \%$ higher on 'Arazá', 'Guenoa' and 'Yvapitá' stock plants, respectively. Nevertheless, average fresh weight of early fruits produced by stock plants was lower on 'Arazá' and 'Guenoa' and higher on 'Yvapitá', when compared to control plants.

Total fruit yield and number of fruits on 'Arazá' and 'Guenoa' plants differed among treatments (Table 2), being lower on control ones. On 'Yvapitá' plants, significant differences were not recorded on plants of all treatments.

The highest plant growth was recorded on T1 'Guenoa' plants and the lowest on control 'Arazá' ones (T5) (Table 3). It was lower on control plants (T5) of 'Arazá' and 'Guenoa', when compared to T1-T4 stock ones. The growth of leaves (petioles included) was lower on Arazá. On plants of this cultivar, it was lower on control plants and did not differ significantly among stock ones. On 'Guenoa' plants, T1, $\mathrm{T} 2$ and $\mathrm{T} 3$ did not differ significantly and reached the higher mean, while the lowest was on control ones. Growth of crown was higher on T1 stock plants and lower on T5-control ones. Dry weight of roots was lower on control plants of 'Arazá' and 'Guenoa'. It has been demonstrated in the literature that during the propagation phase of the strawberry plant, the mother plant, its stolons and daughter plants can exchange assimilates for growth (Savini et al., 2008). Nevertheless, in the present experiment such interactions were minimized, as runner tips were picked out at the first visible root nodule, not being kept to rooting. In this case, it can be considered as weak sink organs,

Table 1. Early fruit yield, number of fruits per plant and average fruit fresh weight of micropropagated (T1) and multiplied strawberry stock plants (T2, T3 and T4) and of control plants (T5) from plug transplants of cultivars Arazá, Guenoa and Yvapitá at the end of the experiment [produção precoce, número de frutos por planta e peso fresco médio de frutos de plantas matrizes de morangueiro micropropagadas (T1) e multiplicadas (T2, T3 e T4) de plantas testemunhas (T5) mudas em bandejas das cultivares Arazá, Guenoa e Yvapitá ao final do experimento]. Santa Maria, UFSM, 2009.

\begin{tabular}{|c|c|c|c|c|c|c|c|c|c|}
\hline \multirow{2}{*}{ Treatments } & \multicolumn{3}{|c|}{ Early fruit yield (g/plant) } & \multicolumn{3}{|c|}{ Fruits (number/plant) } & \multicolumn{3}{|c|}{ Average fruit fresh weight (g) } \\
\hline & Arazá & Guenoa & Yvapitá & Arazá & Guenoa & Yvapitá & Arazá & Guenoa & Yvapitá \\
\hline $\mathrm{T} 1$ & $84.55 \mathrm{BCb} 1$ & 125.70Aa & $34.95 \mathrm{ABc}$ & $15.25 \mathrm{Ab}$ & $19.00 \mathrm{Aa}$ & $3.50 \mathrm{Ac}$ & $5.68 \mathrm{Cb}$ & $6.76 \mathrm{Cb}$ & $9.93 \mathrm{BCa}$ \\
\hline $\mathrm{T} 2$ & $63.09 \mathrm{Cb}$ & $97.33 \mathrm{Ba}$ & $11.91 \mathrm{BCc}$ & $10.15 \mathrm{Ba}$ & $12.09 \mathrm{Ba}$ & $1.06 \mathrm{Ab}$ & $6.34 \mathrm{Cb}$ & $8.03 \mathrm{BCb}$ & $11.09 \mathrm{ABa}$ \\
\hline $\mathrm{T} 3$ & $91.73 \mathrm{ABa}$ & $94.56 \mathrm{Ba}$ & $19.11 \mathrm{BCb}$ & $11.68 \mathrm{Aba}$ & $10.75 \mathrm{Ba}$ & $1.50 \mathrm{Ab}$ & 7.87BCb & $8.81 \mathrm{BCb}$ & $13.08 \mathrm{Aa}$ \\
\hline $\mathrm{T} 4$ & $113.75 \mathrm{Aa}$ & $87.88 \mathrm{Bb}$ & $45.25 \mathrm{Ac}$ & 12.49Aba & 8.50Bab & $4.25 \mathrm{Ac}$ & $9.26 \mathrm{ABa}$ & $10.26 \mathrm{ABa}$ & $10.59 \mathrm{BCa}$ \\
\hline $\mathrm{T} 5$ & $26.92 \mathrm{Db}$ & $47.58 \mathrm{Ca}$ & $8.61 \mathrm{Cb}$ & $2.50 \mathrm{Ca}$ & $4.13 \mathrm{Ca}$ & $1.00 \mathrm{Aa}$ & $11.21 \mathrm{Aa}$ & $11.55 \mathrm{Aa}$ & $8.61 \mathrm{Ca}$ \\
\hline $\mathrm{CV}(\%)$ & & 18.23 & & & 23.53 & & & 12.62 & \\
\hline
\end{tabular}

Means followed by the same lowercase letters in lines and uppercase in columns do not differ by Tukey test at 5\% probability (médias seguidas pela mesma letra minúscula na linha e maiúscula na coluna não diferem significativamente pelo teste de Tukey a $5 \%$ de probabilidade).

Table 2. Total fruit yield, number of fruits per plant and average fruit fresh weight of micropropagated (T1) and multiplied strawberry stock plants (T2, T3 and T4) and of control plants (T5) from plug transplants of cultivars Arazá, Guenoa and Yvapitá at the end of the experiment [produção total de frutos, número de frutos por planta e peso fresco médio de frutos de plantas matrizes de morangueiro micropropagadas (T1) e multiplicadas (T2, T3 e T4) de plantas testemunhas (T5) mudas em bandejas das cultivares Arazá, Guenoa e Yvapitá ao final do experimento]. Santa Maria, UFSM, 2009.

\begin{tabular}{|c|c|c|c|c|c|c|c|c|c|}
\hline \multirow{2}{*}{ Treatments } & \multicolumn{3}{|c|}{ Total fruit yield (g/plant) } & \multicolumn{3}{|c|}{ Fruits (number/plant) } & \multicolumn{3}{|c|}{ Average of fresh fruit (g) } \\
\hline & Arazá & Guenoa & Yvapitá & Arazá & Guenoa & Yvapitá & Arazá & Guenoa & Yvapitá \\
\hline $\mathrm{T} 1$ & $263.82 \mathrm{BCb}$ & $285.42 \mathrm{Bb}$ & $482.20 \mathrm{Aa}$ & $36.75 \mathrm{ABa}$ & $37.25 \mathrm{Aa}$ & $42.00 \mathrm{Aa}$ & $7.20 \mathrm{Ab}$ & $7.77 \mathrm{Bb}$ & $11.60 \mathrm{ABa}$ \\
\hline $\mathrm{T} 2$ & $290.52 \mathrm{ABCb}$ & $315.73 \mathrm{Aab}$ & 402.89Aa & $38.24 \mathrm{ABa}$ & $33.63 \mathrm{Aa}$ & $37.98 \mathrm{Aa}$ & $7.83 \mathrm{Ab}$ & 9.42ABab & $10.46 \mathrm{Ba}$ \\
\hline $\mathrm{T} 3$ & $331.35 \mathrm{ABb}$ & $261.06 \mathrm{ABb}$ & $454.50 \mathrm{Aa}$ & $42.12 \mathrm{Aa}$ & $28.48 \mathrm{ABb}$ & $41.26 \mathrm{Aa}$ & $7.78 \mathrm{Ab}$ & $9.06 \mathrm{ABb}$ & $11.07 \mathrm{ABa}$ \\
\hline $\mathrm{T} 4$ & $384.71 \mathrm{Aa}$ & $361.98 \mathrm{Aa}$ & 406.18Aa & $44.75 \mathrm{Aa}$ & 36.00Aab & $32.25 \mathrm{Ab}$ & $8.64 \mathrm{Ab}$ & $10.08 \mathrm{Ab}$ & $12.73 \mathrm{Aa}$ \\
\hline $\mathrm{T} 5$ & $196.12 \mathrm{Cb}$ & $177.40 \mathrm{Bb}$ & $378.04 \mathrm{Aa}$ & $24.25 \mathrm{Bab}$ & $17.25 \mathrm{Bb}$ & $30.00 \mathrm{Aa}$ & $8.10 \mathrm{Ac}$ & $10.28 \mathrm{Ab}$ & $12.70 \mathrm{Aa}$ \\
\hline CV (\%) & \multicolumn{3}{|c|}{18.06} & \multicolumn{3}{|c|}{20.13} & \multicolumn{3}{|c|}{10.04} \\
\hline
\end{tabular}

Means followed by the same lowercase letters in lines and uppercase in columns do not differ by Tukey test at 5\% probability (médias seguidas pela mesma letra minúscula na linha e maiúscula na coluna não diferem significativamente pelo teste de Tukey a 5\% de probabilidade). 
Table 3. Dry weight of micropropagated (T1) and multiplied strawberry stock plants (T2, T3 and T4) and of control plants (T5) from plug transplants of cultivars Arazá, Guenoa and Yvapitá [peso seco de plantas matrizes de morangueiro micropropagadas (T1) e multiplicadas (T2, T3 e T4) de plantas testemunhas (T5) mudas em bandejas das cultivares Arazá, Guenoa e Yvapitá ao final do experimento]. Santa Maria, UFSM, 2009.

\begin{tabular}{|c|c|c|c|c|c|c|}
\hline \multirow{2}{*}{ Treatments } & \multicolumn{3}{|c|}{ Total dry weight (g/plant) } & \multicolumn{3}{|c|}{ Dry weight of leaves (g/plant) } \\
\hline & Arazá & Guenoa & Yvapitá & Arazá & Guenoa & Yvapitá \\
\hline $\mathrm{T} 1$ & $32.45 \mathrm{Ac}$ & $67.51 \mathrm{Aa}$ & $50.05 \mathrm{ABb}$ & $19.11 \mathrm{Ac}$ & 45.98Aa & $27.92 \mathrm{Bb}$ \\
\hline $\mathrm{T} 2$ & $33.63 \mathrm{Ab}$ & $54.31 \mathrm{Ba}$ & $60.63 \mathrm{Aa}$ & $20.90 \mathrm{Ab}$ & $37.40 \mathrm{ABa}$ & $37.33 \mathrm{Aa}$ \\
\hline $\mathrm{T} 3$ & $31.85 \mathrm{Ab}$ & $53.88 \mathrm{Ba}$ & $53.45 \mathrm{Aa}$ & $20.84 \mathrm{Ab}$ & $37.45 \mathrm{ABa}$ & $\mathrm{ABa}$ \\
\hline $\mathrm{T} 4$ & $29.68 \mathrm{Ab}$ & $47.47 \mathrm{Ba}$ & $41.83 \mathrm{Ba}$ & $19.46 \mathrm{Ab}$ & $33.36 \mathrm{BCa}$ & $28.82 \mathrm{ABa}$ \\
\hline T5 & $11.54 \mathrm{Bc}$ & $30.07 \mathrm{Cb}$ & $40.71 \mathrm{Ba}$ & $8.85 \mathrm{Bb}$ & $25.46 \mathrm{Ca}$ & $32.78 \mathrm{ABa}$ \\
\hline & 27.83 & 50.65 & 49.33 & 17.83 & 35.93 & 32.22 \\
\hline $\mathrm{CV}$ & & 121 & & & 15.47 & \\
\hline
\end{tabular}

\begin{tabular}{|c|c|c|c|c|c|c|}
\hline \multirow[b]{2}{*}{$\mathrm{T} 1$} & \multicolumn{3}{|c|}{ Crown dry weight (g/plant) } & \multicolumn{3}{|c|}{ Root dry weight (g/plant) } \\
\hline & $11.05 \mathrm{Ab}$ & $14.24 \mathrm{Aa}$ & $16.31 \mathrm{Aa}$ & $2.30 \mathrm{BCb}$ & 7.29Aa & $5.82 \mathrm{ABa}$ \\
\hline $\mathrm{T} 2$ & $7.53 \mathrm{Bb}$ & $8.74 \mathrm{Bb}$ & $12.68 \mathrm{Ba}$ & $5.19 \mathrm{Ac}$ & $8.18 \mathrm{Ab}$ & $10.62 \mathrm{Aa}$ \\
\hline $\mathrm{T} 3$ & $6.36 \mathrm{Bb}$ & $8.17 \mathrm{Bb}$ & $12.29 \mathrm{Ba}$ & $4.65 \mathrm{Ab}$ & $8.27 \mathrm{Aa}$ & $6.88 \mathrm{Ba}$ \\
\hline $\mathrm{T} 4$ & $6.69 \mathrm{Ba}$ & $7.09 \mathrm{Ba}$ & $7.79 \mathrm{Ca}$ & $3.54 \mathrm{ABc}$ & $7.03 \mathrm{Aa}$ & $5.22 \mathrm{ABb}$ \\
\hline T5 & $1.08 \mathrm{Ca}$ & $1.82 \mathrm{Ca}$ & $3.17 \mathrm{Da}$ & $1.62 \mathrm{Cb}$ & $2.79 \mathrm{Bb}$ & $4.77 \mathrm{Ba}$ \\
\hline Avera & 6.54 & 8.01 & 10.45 & 3.46 & 6.71 & 6.66 \\
\hline $\mathrm{CV}(\%)$ & \multicolumn{3}{|c|}{17.22} & \multicolumn{3}{|c|}{16.37} \\
\hline
\end{tabular}

Means followed by the same lowercase letters in lines and uppercase in columns do not differed by Tukey test at $5 \%$ probability (médias seguidas pela mesma letra minúscula na linha e maiúscula na coluna não diferem significativamente pelo teste de Tukey a $5 \%$ de probabilidade).

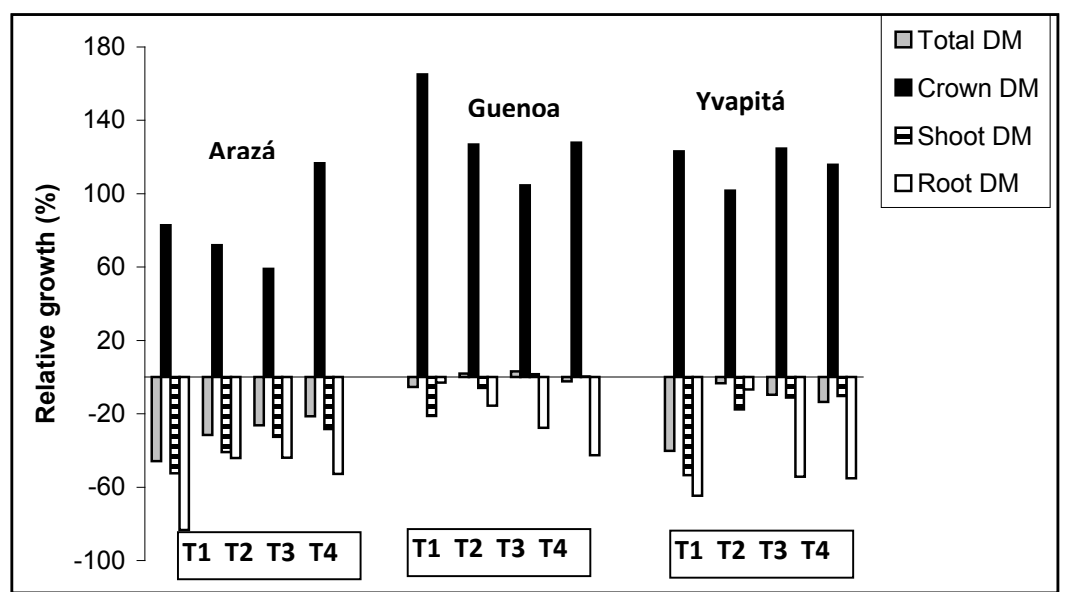

Figure 1. Relative growth of strawberry plants of cultivars Arazá, Guenoa and Yvapitá between planting as stock plants and the end of the fruiting period; $\mathrm{T} 1=$ micropropagated stock plants; T2, T3 and T4= multiplied stock plants; DM= dry mass [crescimento relativo de plantas de morangueiro das cultivares Arazá, Guenoa e Yvapitá entre o plantio das plantas matrizes e o final do período de frutificação; T1= plantas matrizes micropropagadas; T2, T3 e T4 plantas matrizes multiplicadas; DM= massa seca]. Santa Maria, UFSM, 2009.

because of the vigorous growth of the stock plants at the end of the propagation phase. This growth was reduced during the reproductive phase. Figure 1 shows that shoot and roots lost dry weight the perennial trait of this plant species.

Early strawberry fruit yield is an important characteristic, because of higher fruit prices in fall and winter (Hokanson et al., 2004). Results of the present experiment clearly demonstrate that previous plant growth before the beginning of the fruiting period can stimulate early fruit yield. This was shown mainly by the number of fruits per plant, which can be attributed to a higher number of meristematic apexes in older plants. In young plants originated from transplants, the emission of inflorescences depends on the previous growth of the crown, in an isometric physiological process. Nevertheless, higher number of fruits per plant leads to lower fruit fresh weight, probably due to defoliation, which reduces the supply of photosynthetic assimilates. This hypothesis is reinforced by the low fruit fresh weight observed in micropropagated stock plants with the higher growth (T1). Higher dry weight implies higher maintenance respiration, increasing competition for assimilates between leaves and inflorescences growing simultaneously. Thus, this competition stops after the emission of new leaves on defoliated plants, as well as fruit yield between the ending date of the early period and the end of the experiment was also higher on stock plants. The convenience of the defoliation practice at the beginning of the second cropping year has to be reviewed, especially in well-conducted crops that are free of pests and diseases.

The present results show that in soilless growing system, strawberry stock plants can reach a higher early and total fresh fruit yield than plug transplants. Therefore, they should not be discarded after the production of runner tips.

\section{ACKNOWLEDGEMENTS}

We thank the Conselho Nacional de Desenvolvimento Científico e Tecnológico (CNPq) for the financial support to conduct this research and to Coordenação de Aperfeiçoamento de Pessoal de Nível Superior (CAPES) for the fellowship. 


\section{REFERENCES}

ANTUNES OT; CALVETE EO; ROCHA HC; NIENOW AA; CECCHETTI E; RIVA DE; MARAN RE. 2007. Produção de cultivares de morangueiro polinizadas pela abelha jataí em ambiente protegido. Horticultura Brasileira 25: 094-099.

C R O P-S P E C I F I C P R O T O C O L STRAWBERRIES, 2011. Available in: http://assurance.redtractor.org.uk/ resources/000/616/224/Strawberries_2011. pdf. Accessed in January 25, 2012.

DURNER EF; POLING EB; MAAS JL. 2002. Recent advances in strawberry plug transplant technology. HortTechnology 12: 545-550.

GIMENEZ G; ANDRIOLO JL; GODOI RS. 2008. Cultivo sem solo do morangueiro. Ciência
Rural 38: 273-279.

HEIDE OM; SONSTEBY A. 2007. Interactions of temperature and photoperiod in the control of flowering of latitudinal and altitudinal populations of wild strawberry (Fragaria vesca). Physiologia Plantarum 130: 280-289.

HOKANSON SC; TAKEDA F; ENNS JM; BLACK BL. 2004. Influence of plant storage duration on strawberry runner tip viability and field performance. HortScience 39: 1596-1600.

MEIER U; GRAF H; HACK M; HESS M; KENNEL W; KLOSE R; MAPPES D; SEIPP D; STAUSS R; STREIF J; VAN DEN BOOM D. 1994. Phenological devel-feed is the pome fruit (Malus domestica Borkh. and Pyrus communis L.), the stone fruits (Prunus spp), the currant (Ribes species) and the strawberry (Fragaria x ananassa Duch.). Nachrichtenblatt Deutschland Pflanzenschutz 46: 141-153.

OLIVEIRA RP; SCIVITTARO WB. 2006. Desempenho produtivo de mudas nacionais e importadas de morangueiro. Revista Brasileira de Fruticultura 28: 520-522.

SAVINI G; GIORGI V; SCARANO E; NERI D. 2008. Strawberry plant relationship through the stolon. Physiologia Plantarum 134: 421-429.

TESSARIOLI NETO J; ORTIGOZA LER; VERDIAL MF. 2003. Produção de mudas de morangueiro em duas épocas de coleta. Horticultura Brasileira 21: 231-233.

VICENTE E; GIMÉNEZ G; MANZZIONI A; VILARÓ F; GONZÁLEZ M; CABOT M. 2009. Strawberry breeding in Uruguay. Acta Horticulturae 842: 411-41. 